\title{
Scrapie Agent Proteins Do Not Accumulate in Grey Tremor Mice
}

\author{
By PAUL E. BENDHEIM, ${ }^{1 *}$ ALAN D. MARMORSTEIN ${ }^{2}$ \\ ANNA POTEMPSKA ${ }^{1}$ AND DAVID C. BOLTON ${ }^{2}$ \\ Departments of ${ }^{1}$ Pathological Neurobiology and ${ }^{2}$ Molecular Biology, New York State Institute \\ for Basic Research in Developmental Disabilities, 1050 Forest Hill Road, Staten Island, \\ New York 10314, U.S.A.
}

(Accepted 18 December 1987)

\section{SUMMAR Y}

The grey tremor mouse is an autosomal recessive mutant characterized by a phenotype of unusual pigmentation, neurological abnormalities and early death. These mice have a spongiform encephalopathy similar to scrapie and Creutzfeldt-Jakob disease. Although the disease is clearly heritable, the grey tremor mouse spongiform pathology has also been transmitted by inoculation of genetically normal mice with diseased brain homogenates. The possibility that a scrapie-like agent is involved has been proposed. We examined brain homogenates from grey tremor mice, scrapieaffected mice and normal mice for the presence of the mouse scrapie agent protein (MoSp33-37) and its normal cellular homologue. All untreated homogenates contained one or both isoforms of this protein as detected on immunoblots. Grey tremor mouse brain homogenates, when protease-treated, showed no evidence of MoSp33-37. A purification method for MoSp33-37 concentrated it in samples from scrapie-affected mice, but this protein was not detected in grey tremor or normal mice. These results suggest that it is unlikely that the scrapie agent is involved in grey tremor disease.

Mice homozygous for the grey tremor (GT) trait (gt/gt) display a characteristic pigmentation of their coats, seizures, tremors, ataxia and death by 90 days of age (Sidman et al., 1985). The neuropathology is a non-inflammatory spongiform appearance to the brain (Kinney \& Sidman, 1986) resembling that of the transmissible spongiform diseases scrapie and Creutzfeldt-Jakob disease (CJD). The spongiform neuropathology, but not the neurological syndrome characteristic of the homozygote gt/gt, was transmitted to genetically normal mice by inoculation with $\mathrm{gt} / \mathrm{gt}$ brain homogenates (Sidman et al., 1985). In a second report on transmission of GT disease, NFS/N mice were inoculated with gt/gt brain homogenate (Hoffman et al., 1987). Sixty days later they started to display a syndrome of tremulousness that progressed over 300 to 400 days to a marked ataxia, spasticity and bradykinesia. This transmitted syndrome was different to that which occurred in gt/gt homozygotes and differed from the syndromes which appeared in NFS/N mice inoculated with either a murine leukaemia virus or with the scrapie agent.

Mouse scrapie is a stereotypic clinical and neuropathological disease experimentally reproduced by intracerebral inoculation of the scrapie agent into animals. In C57BL mice inoculated with the ME7 strain of the scrapie agent a silent incubation period of 120 to 180 days is followed by a uniformly fatal neurological syndrome lasting 3 to 4 weeks. The major signs are a hunched posture, ataxia, tremulousness and preterminal immobility. The disease course and clinical signs of scrapie in mice are distinct from those of GT disease.

The physicochemical nature of the agents responsible for scrapie in animals and CJD, kuru and the Gerstmann-Straussler syndrome in humans is not completely defined (reviewed by Carp et al., 1985; Diener, 1987). However, in all natural and experimental hosts examined, unique, scrapie-specific proteins have been detected (Bolton et al., 1982, 1984; Bendheim et al., 1985; Bockman et al., 1987; Rubenstein et al., 1987). In each species these proteins are derived from a 


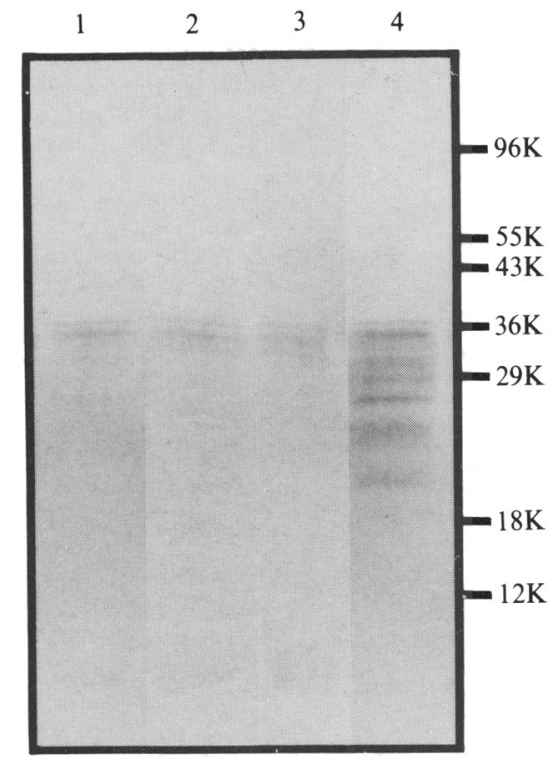

Fig. 1. Identification of MoCp33-37 and MoSp33-37 by immunoblotting. Brain homogenates $(10 \% \mathrm{w} / \mathrm{v})$ were made from single brains in $0.32 \mathrm{M}$-sucrose using a glassTeflon homogenizer. An aliquot of each homogenate was diluted with distilled water and SDS-PAGE sample buffer $(62.5 \mathrm{~mm}$-Tris-HCl, $2 \% \mathrm{SDS}, 5 \% 2$-mercaptoethanol, $10 \%$ glycerol, $0 \cdot 0002 \%$ bromophenol blue, $\mathrm{pH} 6 \cdot 8$ ) to a final concentration of $25 \mathrm{mg} / \mathrm{ml}$. Samples from unaffected $(+/ \mathrm{gt}$ or $+/+)$ GT littermates (lane 1$)$, symptomatic GT homozygotes (gt/gt) (lane 2), normal C57BL mice (lane 3) and scrapie-affected C57BL mice (lane 4) were subjected to SDS-PAGE and analysed by immunoblotting using an antiserum generated against PrP27-30, a protease-resistant fragment of the scrapie protein (Bendheim et al., 1984). Molecular size markers are indicated.

single normal host gene encoding a cellular protein of unknown function (Oesch et al., 1985; Basler et al., 1986; Locht et al., 1986; Robakis et al., 1986). The abnormal form of this protein is only detected in scrapie- and CJD-diseased brains and its amount correlates with the amount of biologically active agent (McKinley et al., 1983; Brown et al., 1986; Bolton et al., 1987). This and other experimental data implicate this protein as the major structural protein of the transmissible agent. In the literature the terms 'scrapie agent protein', 'protease-resistant protein' and 'prion protein' have been used in reference to those proteins. In this report we use the term scrapie agent protein $(\mathrm{Sp33-37)}$ for the intact protein and protease-resistant protein (PrP) for the truncated form produced by protease digestion of the intact protein (Bolton et al., 1987).

We searched for scrapie agent-specific proteins in GT mouse brain to investigate further the suggestion by Sidman et al. (1985) that the scrapie agent might be involved in the transmission of the spongiform encephalopathy characteristic of this mutant.

Mice were purchased from Jackson Laboratories (Bar Harbor, Me., U.S.A.). All gt/gt mice displayed the coat colour and marked neurological impairment characteristic of this strain. Littermates of the gt/gt homozygotes were phenotypically normal $+/ g$ theterozygotes or $+/+$ homozygotes. C57BL mice inoculated intracerebrally with scrapie agent strain ME7 served as scrapie-positive controls and uninoculated age-matched C57BL mice were normal controls. Grey tremor mice and their littermates were sacrificed at 50 to 72 days of age, scrapie-affected C57BL mice at 120 to 140 days post-inoculation (165 to 220 days of age) and normal C57BL mice at 165 to 220 days of age.

Fig. 1 is an immunoblot of proteins in brain homogenates of phenotypically normal GT littermates (either $+/ g t$ or $+/+$ ) (lane 1 ), symptomatic GT gt/gt mutants (lane 2), normal C57BL mice (lane 3) and scrapie-affected C57BL mice (lane 4). The antiserum used was raised against the hamster scrapie agent protein (Bendheim et al., 1984) and has been shown to identify the major mouse scrapie agent proteins (Bendheim \& Bolton, 1986). It also recognizes the cellular protein $(\mathrm{Cp} 33-37)$ which is the normal translation product of the gene encoding both isoforms of this protein. Immunoreactive proteins of $M_{\mathrm{r}} 33 \mathrm{~K}$ to $37 \mathrm{~K}$ were detected in all four samples. In the scrapie agent-containing sample (lane 4) darker staining is evident, as well as staining of several additional lower $M_{\mathrm{r}}$ proteins. This pattern of immunoreactivity suggests the presence of increased amounts of mouse scrapie agent protein (MoSp33-37) or mouse cellular protein (MoCp33-37) when compared with lanes 1 to 3 . That proteins were identified in the 


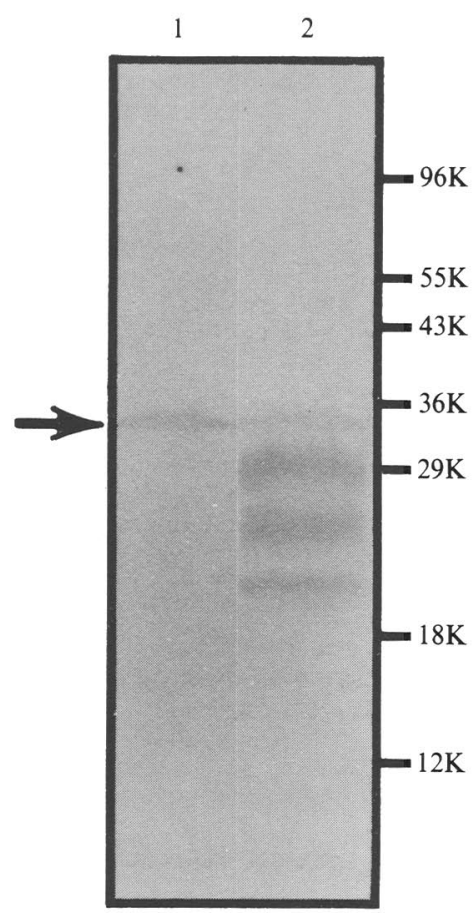

Fig. 2.

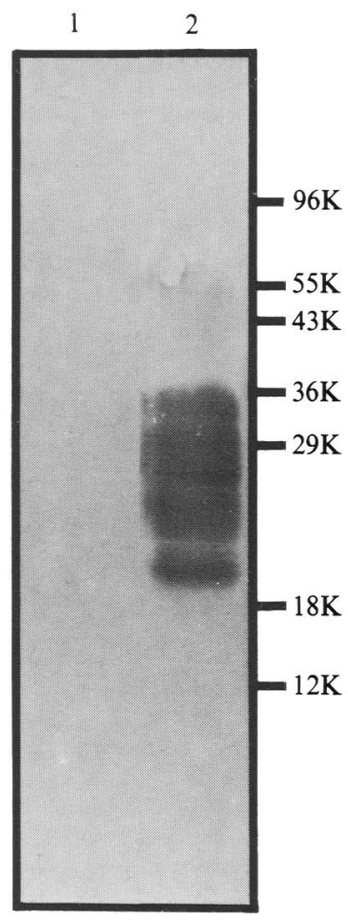

Fig. 3.

Fig. 2 Protease digestion of proteins in GT and scrapie-affected mouse brains. Aliquots of the homogenates shown in Fig. I, lanes 2 and 4 , were incubated for $30 \mathrm{~min}$ at $37^{\circ} \mathrm{C}$ with $50 \mu \mathrm{g} / \mathrm{ml}$ proteinase K (EM Reagents, F.R.G.). The reaction was stopped by the addition of PMSF (Sigma, final concentration $20 \mathrm{mM}$ ), SDS-PAGE sample buffer and heating at $100^{\circ} \mathrm{C}$ for 5 min prior to SDS-PAGE and immunoblotting as described in Fig. 1. Lane 1, GT homozygote; lane 2, scrapie-affected C57BL. The scrapie agent-specific protein bands present in lane 2 are absent from lane 1 . The arrow indicates that in both lanes proteinase $\mathrm{K}$ was recognized by this antiserum (Bendheim et al., 1984).

Fig. 3. Purification of MoSp33-37 is possible from scrapie-affected mouse brain, but not from GT mouse brain. Two brains each from C57BL mice with scrapie and GT mice were processed using a modification of a method developed to purify the scrapie agent protein from hamster brain (Bolton $e t$ $a l ., 1987)$. Pellets $\left(\mathrm{P}_{4}\right)$ so prepared were resuspended in nuclease digestion buffer $(10 \mathrm{~mm}-\mathrm{Tris}-\mathrm{HCl}, 100$ $\left.\mathrm{mm}-\mathrm{NaCl}, 5 \mathrm{~mm}-\mathrm{CaCl}_{2}, 5 \mathrm{~mm}-\mathrm{MgCl}_{2}, \mathrm{pH} \mathrm{7.4}\right)$. RNase A $(100 \mu \mathrm{g} / \mathrm{ml})$ and DNase I $(20 \mu \mathrm{g} / \mathrm{ml})$ were added and the suspensions incubated for $2 \mathrm{~h}$ at room temperature with continuous stirring. EDTA, $\mathrm{NaCl}$ and Sarkosyl were added to final concentrations of $50 \mathrm{~mm}, 10 \%(\mathrm{w} / \mathrm{v})$ and $1 \%$, respectively, and the samples were sedimented in a microcentrifuge for $30 \mathrm{~min}$ at room temperature. The pellets $\left(\mathrm{P}_{5}\right)$ from a GT gt/gt preparation (lane 1) and a scrapie-affected C57BL preparation (lane 2) were analysed on an immunoblot as described in Fig. 1.

diseased gt/gt mice and their normal littermates (lanes 1 and 2) demonstrated that the brains of these mice contained one or both isoforms of the $33 \mathrm{~K}$ to $37 \mathrm{~K}$ protein. However, these results could not distinguish between the two isoforms.

When brain homogenates are treated with proteinase $\mathrm{K} \mathrm{Cp} 33-37$ is completely degraded (Barry et al., 1985). This criterion of differential protease sensitivity allows the distinction between the two isoforms of the protein to be made. In an attempt to determine whether MoSp33-37 was present at low concentration in GT mice, but obscured by MoCp33-37, a sample of the GT brain homogenate was treated with proteinase K. An aliquot of the scrapieaffected C57BL mouse brain homogenate was used as a control. In the GT sample no degradation-resistant scrapie agent proteins were detected (Fig. 2, lane 1). Scrapie agentspecific PrPs were detected in the scrapie-affected C57BL mouse sample (Fig. 2, lane 2). These proteins have apparent $M_{\mathrm{r}} \mathrm{s}$ of $28 \mathrm{~K}$ to $31 \mathrm{~K}, 23 \mathrm{~K}$ to $26 \mathrm{~K}$ and $21 \mathrm{~K}$ and are similar to those 
Table 1. Features of grey tremor and scrapie in mice

Heritable
Transmissible pathology
Transmissible clinical disease
Cp33-37
Sp33-37
Scrapie-associated fibrils
Chromosomal localization $\dagger$

* + , Present; - , absent.

† The gt mutation has been linked to the caracul locus on chromosome 15 (Sidman et al., 1985). The gene(s) for scrapie incubation period control and encoding Cp33-37 and Sp33-37 are on chromosome 2 (Sparkes et al., 1986; Carlson et al., 1986).

described previously (Bolton et al., 1984; Kascsak et al., 1986). The staining of proteinase $\mathrm{K}$ by the antiserum used in this experiment (Fig. 2, lanes 1 and 2, arrow) has also been noted before (Bendheim et al., 1984). These results demonstrated that no protease-resistant scrapie agent proteins were detected in GT brain and indicated that MoCp33-37 was predominant, if not the only, isoform of the protein that had been detected in the homogenate of GT brain (Fig. 1, lane 2).

It was still possible that MoSp33-37 was present in GT brain homogenates at a concentration below that required for detection on immunoblots. Therefore, an attempt was made to purify and concentrate this protein from GT mouse brains. Cp33-37 and Sp33-37 can be separated on the basis of their different physical properties by a method previously described for the purification of the intact scrapie agent protein from diseased hamster brains (Bolton et al., 1987). As demonstrated in Fig. 1, an isoform of the protein was present in the initial GT brain homogenate. However, scrapie agent proteins were not detected in the $\mathbf{P}_{5}$ fraction from $G T$ mouse brain (Fig. 3, lane 1). MoSp33-37 and several lower $M_{\mathrm{r}}$ antigenically related proteins were readily detected in the $P_{5}$ fraction from scrapie-affected C57BL mice (Fig. 3, lane 2), demonstrating that scrapie agent proteins were concentrated in this fraction. The lower $M_{\mathrm{r}}$ proteins probably represent degradation products of MoSp33-37 or incompletely processed forms of the primary translation product. These results demonstrated that MoSp33-37 was not purified from gt/gt brains using this procedure for isolating the scrapie agent.

The cardinal features of GT disease and scrapie are summarized in Table 1. The pathological features of the spongiform encephalopathy of the GT mutant resembles those of scrapie, although clinical features of the two diseases differ. Scrapie is transmissible in its entirety: host animals develop the characteristic clinical syndrome and neuropathology. Previous work on the GT mutant demonstrated that the pathological changes characteristic of the homozygote could be transmitted to genotypically normal mice after an incubation period as long as 2 years (Sidman et al., 1985). Mice inoculated with $\mathrm{gt} / \mathrm{gt}$ brain homogenates did not develop a clinical syndrome resembling that of either the gt/gt homozygote or scrapie (Sidman et al., 1985; Hoffman et al., 1987). Some mice appeared abnormal after inoculation, but when progression of clinical disease occurred it was milder and slower than in the $\mathrm{gt} / \mathrm{gt}$ mutant. This is in marked contradistinction to scrapie-affected mice, all of which demonstrate a relentless progression of neurological signs leading to death within weeks after the onset of disease.

The scrapie protein, Sp33-37, accumulates in all animals with scrapie and similar proteins accumulate in humans and experimental animals with CJD. It is a modified form of a normal, host-derived protein. The two forms of the protein differ in certain physical properties and have been distinguished and separated on this basis (Meyer et al., 1986; Hope et al., 1986; Bolton et al., 1987). Our results demonstrate that GT mice contain only the normal isoform. It appears to be present in quantities similar to those in normal mice of other strains. No evidence for the presence of the scrapie agent protein was found in either GT brain homogenates treated with proteinase $\mathrm{K}$ or in $\mathrm{P}_{5}$ fractions from a purification protocol used to isolate the abnormal protein and the biologically active scrapie agent. 
The absence of the scrapie isoform of the protein argues against the scrapie agent being involved in the transmission of the GT pathology. These results are consistent with those of others. Scrapie-associated fibrils have been detected in all the natural or experimental animal and human transmissible spongiform encephalopathies caused by scrapie or CJD agents (Merz et al., 1984). These characteristic fibrils have not been detected in GT brains (Sidman et al., 1985; Hoffman et al., 1987). The single gene encoding both MoSp33-37 and MoCp33-37 is on chromosome 2 in the mouse (Sparkes et al., 1986). This gene is closely linked to, and may be identical with, the primary gene controlling scrapie incubation period duration (Carlson et al., 1986). The GT mutation is linked to chromosome 15 (Sidman et al., 1985). Therefore, the agent responsible for experimental transmission of the GT spongiform neuropathology remains to be identified, but these data indicate that the scrapie agent is not the pathogen.

Dr Paul Hoffman and colleagues shared their results prior to publication. This work was supported in part by an American Federation for Ageing Research grant (P.E.B.) and USPHS grant NS 23948 (D.C.B.). Mrs Pat Casiano prepared the manuscript.

\section{REFERENCES}

BARry, R. A., Mckinley, M. P., BENDheim, P. E., LEWIS, G. K., DeARMOND, S. J. \& PRUSINER, S. B. (1985). Antibodies to the scrapie protein decorate prion rods. Journal of Immunology 135, 603-613.

BASLER, K., OESCH, B., SCOTT, M., WESTAWAY, D., WALCHLI, M., GROTH, D. F., MCKINLEY, M. P., PRUSINER, S. B. \& weissmann, C. (1986). Scrapie and cellular PrP isoforms are encoded by the same chromosomal gene. Cell 46, $417-428$.

BENDHEIM, P. E. \& BOLTON, D. C. (1986). A 54-kDa normal cellular protein may be the precursor of the scrapie agent protease-resistant protein. Proceedings of the National Academy of Sciences, U.S.A. 83, 2214-2218.

BENDHEIM, P. E., BARRY, R. A., DeARMOND, S. J., STITES, D. P. \& PRUSINER, S. B. (1984). Antibodies to a scrapie prion protein. Nature, London 310, 418-421.

Bendheim, P. E., BOCKMAN, J. M., McKinley, M. P., KINGsbury, D. T. \& PRusiner, s. B. (1985). Scrapie and Creutzfeldt-Jakob disease prion proteins share physical properties and antigenic determinants. Proceedings of the National Academy of Sciences, U.S.A. 82, 997-1001.

BOCKMAN, J. M., PRUSiner, S. B., TATEISHI, J. \& KINGSBURY, D. T. (1987). Immunoblotting of Creutzfeldt-Jakob disease prion proteins: host species-specific epitopes. Annals of Neurology 21, 589-595.

BOLTON, D. C., MCKINLEY, M. P. \& PRUSINER, S. B. (1982). Identification of a protein that purifies with the scrapie prion. Science 218, 1309-1311.

BOLTON, D. C., MCKINLEY, M. P. \& PRUSINER, S. B. (1984). Molecular characteristics of the major scrapie prion protein. Biochemistry 23, 5898-5906.

BOLTON, D. C., BENDHEIM, P. E., MARMORSTEIN, A. D. \& POTEMPSKA, A. (1987). Isolation and structural studies of the intact scrapie agent protein. Archives of Biochemistry and Biophysics 258, 579-590.

BROWN, P., COKER-VANN, M., POMEROY, K., FRANKO, M., ASHER, D. M., GIBBS, C. J., JR \& GAJDUSEK, D. C. (1986). Diagnosis of Creutzfeldt-Jakob disease by Western blot identification of marker protein in human brain tissue. New England Journal of Medicine 314, 547-551.

CARLSON, G. A., KINGSBURY, D. T., GOODMAN, P. A., COLEMAN, S., MARShaLl, S. T., DeARMOND, S. J., WeSTAWAY, D. \& PRUSINER, S. B. (1986). Linkage of prion protein and scrapie incubation time genes. Cell 46, 503-511.

CARP, R. I., MERZ, P. A., KASCSAK, R. J., MERZ, G. S. \& WISNIEWSKI, H. M. (1985). Nature of the scrapie agent : current status of facts and hypotheses. Journal of General Virology 66, 1357-1368.

DIENER, T. O. (1987). PrP and the nature of the scrapie agent. Cell 49, 719-721.

hOFFMAN, P. M., ROHWER, R. G., MACAULEY, C., BILELlO, J. A., HARTLEY, J. W. \& MORSE, H. C. (1987). Transmission in NFS/N mice of the heritable spongiform encephalopathy associated with the grey tremor mutation. Proceedings of the National Academy of Sciences, U.S.A. 84, 3866-3870.

HOPE, I., MORTON, L. J. D., FARQUHAR, C. F., MULTHAUP, G., BEYREUTHER, K. \& KIMBERLIN, R. H. (1986). The major polypeptide of scrapie-associated fibrils (SAF) has the same size, charge distribution, and N-terminal protein sequence as predicted for the normal brain protein (PrP). EMBO Journal 5, 2591-2597.

KASCSAK, R. J., RUBENSTEIN, R., MERZ, P. A., CARP, R. I., ROBAKIS, N. K., WISNIEWSKI, H. M. \& DIRINGER, H. (1986). Immunological comparison of scrapie-associated fibrils isolated from animals infected with four different scrapie strains. Journal of Virology 59, 676-683.

KINNEY, H. C. \& SIDMAN, R. L. (1986). Pathology of the spongiform encephalopathy in the gray tremor mutant mouse. Journal of Neuropathology and Experimental Neurology 45, $108-126$.

LOCHT, C., CHESEBRO, B., RACE, R. \& XEITH, J. M. (1986). Molecular cloning and complete sequence of prion protein cDNA from mouse brain infected with the scrapie agent. Proceedings of the National Academy of Sciences, U.S.A. 83, 6372-6376.

MCKINLEY, M. P., BOLTON, D. C. \& PRUSINER, S. B. (1983). A protease-resistant protein is a structural component of the scrapie prion. Cell 35, 57-62. 
MERZ, P. A., ROHWER, R. G., KASCSAK, R., WISNIEWSKI, H. M., SOMERVILLE, R. A., GIBBS, C. J., JR \& GAJDUSEK, D. C. (1984). Infection-specific particle from the unconventional slow virus diseases. Science 225, 437-440.

MEYER, R. K., MCKINLEY, M. P., BOWMAN, K. A., BRAUNFELD, M. B., BARRY, R. A. \& PRUSINER, S. B. (1986). Separation and properties of cellular and scrapie prion proteins. Proceedings of the National Academy of Sciences, U.S.A. 83, 2310-2314.

OESCH, B., WESTAWAY, D., WALCHLI, M., MCKINLEY, M. P., KENT, S. B. H., AEBERSOLD, R., BARRY, R. A., TEMPST, P., TEPLOW, D. B., HOOD, L. E., PRUSINER, S. B. \& WEISSMANN, C. (1985). A cellular gene encodes scrapie PrP27-30 protein. Cell 40, 735-746.

ROBAKIS, N. K., SAWH, P. R., WOLFE, G. C., RUBENSTEIN, R., CARP, R. I. \& INNIS, M. A. (1986). Isolation of a cDNA clone encoding the leader peptide of prion protein and expression of the homologous gene in various tissues. Proceedings of the National Academy of Sciences, U.S.A. 83, 6377-6381.

RUBENSTEIN, R., MERZ, P. A., KASCSAK, R. J., CARP, R. I., SCALICI, C. L., FAMA, C. L. \& WiSNIEWSKI, H. M. (1987). Detection of scrapie-associated fibrils (SAF) and SAF proteins from scrapie-affected sheep. Journal of Infectious Diseases 156, 36-42.

SIDMAN, R. L., KINNEY, H. C. \& SWEET, H. O. (1985). Transmissible spongiform encephalopathy in the gray tremor mutant mouse. Proceedings of the National Academy of Sciences, U.S.A. 82, 253-257.

SPARKES, R. S., SIMON, M., COHEN, V. H., FOURNIER, R. E. K., LEM, J., KLISAK, I., HEINZMANN, C., BLATT, C., LUCERO, M., MOHANDAS, T., DeARMOND, S. J., WESTAWAY, D., PRUSiner, S. B. \& WEINER, L. P. (1986). Assignment of the human and mouse prion protein genes to homologous chromosomes. Proceedings of the National Academy of Sciences, U.S.A. 83, 7358-7362.

(Received 12 October 1987) 